\title{
PENGARUH RISIKO SISTEMATIS DAN LIKUIDITAS TERHADAP RETURN SAHAM PADA PERUSAHAAN MANUFAKTUR YANG TERDAFTAR DI BEI
}

\author{
Inggit Nugroho \\ Sukhemi* \\ Fakultas Ekonomi Universitas PGRI Yogyakarta \\ *khemi_mukha@yahoo.co.id
}

\begin{abstract}
The purpose of this research was to examine the effect of systematic risk and liquidity toward stock returns in companies listed on the Indonesia Stock Exchange in the period of 20122014 by using single index model. The population of this research was manufacturing company listed on the Indonesia Stock Exchange.

The data used in this research were secondary data obtained from www.idx.co.id. The sample of the research was manufacturing companies listed on the Indonesia Stock Exchange. The sample was determined by purposive sampling method, thus obtained 33 companies. Systematic risk was measured by beta, while liquidity was measured by current ratio. The data were analyzed using classic assumption test, multiple regression, simultaneous regression and partial regression.

Based on the result of multiple regression analysis with significance level of 5\%, the result of this research showed that: the systematic risk (beta) showed negative significant effect on stock returns on companies listed on the Indonesia Stock Exchange, while liquidity had no effect on stock returns on companies listed on the Indonesia Stock Exchange.
\end{abstract}

Keywords: systematic risk, beta, stocks, liquidity and stock returns.

\section{PENDAHULUAN}

Pasar modal Indonesia mengalami perkembangan sangat pesat, seiring terus berkembangnya pasar modal dunia dan kemajuan teknologi. Pasar modal adalah tempat pertemuan antara penawaran dengan permintaan surat berharga, di tempat inilah para pelaku pasar yaitu individu-individu atau badan usaha yang mempunyai kelebihan dana melakukan investasi dalam surat berharga yang ditawarkan oleh emiten. Di tempat ini perusahaan yang membutuhkan dana menawarkan surat berharga dengan cara listing terlebih dahulu pada badan otoritas di pasar modal sebagai emiten (Sunariyah, 2006:5).

Adanya pasar modal, perusahaan mempunyai kesempatan untuk memperoleh sumber dana lain yang bersumber dari masyarakat. Pada umumnya hampir semua investasi mengandung unsur ketidakpastian. Keadaan semacam itu dikatakan bahwa investor tersebut menghadapi risiko dalam investasi.Investor hanya mampu memperkirakan berapa keuntungan yang diharapkan dari investasinya, dan seberapa jauh kemungkinan hasil yang sebenarnya nanti akan menyimpang dari hasil yang diharapkan. Apabila investor ingin memperoleh tingkat keuntungan yang tinggi, maka ia harus bersedia menanggung risiko yang tinggi juga. Oleh karena itu,dalam melakukan investasi pihak investor seharusnya mempertimbangkan secaramatang mengenai beberapa hal yang sangat penting di dalam pengambilan keputusan investasi, hal yang perlu diperhatikan yaitu berapatingkat return yang diharapkannya, beberapa besar risiko yang harus ditanggungnya dan beberapa likuiditas investasi tersebut (Mustikaningjati, 2005) dalam ( Alfred, 2005).

Menurut Halim (2002:40) terdapat dua macam jenis risiko portfolio yang dihadapi investor yaitu risiko sistematis dan risiko non sistematis. Risiko sistematis adalah suatu risiko yang tidak dapat dihilangkan dengan melakukan diversifikasi, karena fluktuasi risiko ini menjelaskan faktor makro yang dapat 
mempengaruhi pasar secara keseluruhan seperti perubahan tingkat bunga, kurs valuta asing, dan kebijakan pemerintah. Risiko nonsistematis merupakan suatu risiko yang dapat dihilangkan dengan melakukan diversifikasi, karena risiko ini hanya ada dalam satu perusahaan atau industri tertentu. Faktor-faktor yang mempengaruhi risiko non-sistematis ini antara lain struktur modal, struktur asset, dan tingkat likuiditas.

Parameter yang bisa digunakan untuk menghitung risiko sistematis adalah beta. Risiko sistematis atau risiko pasar disebut dengan beta $(\beta)$, merupakan koefisien dari fungsi positif dan linear return pasar terhadap return saham, dimana beta ini merupakan faktor yang paling dominan dalam mempengaruhi return saham. Beta merupakan ukuran kepekaan return sekuritas terhadap return pasar. Semakin besar beta suatu sekuritas, semakin besar kepekaan return sekuritas tersebut terhadap perubahan return pasar. Menurut Husnan (2005:200) hubungan return saham dengan risiko sistematis digambarkan sebagai hubungan linier positif, artinya semakin tinggi risiko yang akan ditanggung oleh investor maka semakin besar return saham yang diharapkan oleh investor. Dengan kata lain investor yang berharap memperoleh tingkat keuntungan yang tinggi, berarti bersedia menanggung risiko yang tinggi.

Untuk menilai kinerja dan prospek perusahaan ke depan, investor juga bisa melihat dari tingkat likuiditas perusahaan. Likuiditas adalah kemampuan perusahaan untuk memenuhi kewajiban jangka pendeknya (Fahmi, 2013:147). Sehingga investor dapat menerima return yang tinggi dan sebaliknya. Pada penelitian ini untuk mengukur tingkat likuiditas perusahaan digunakan rasio lancar (current ratio). Menurut Kashmir (2011:134) rasio lancar atau current ratio merupakan rasio untuk mengukur kemampuan perusahaan dalan membayar kewajiban jangka pendek atau hutang yang segera jatuh karena tempo pada saat ditagih secara keseluruhan.

Semakin besarnya likuiditas perusahaan yang dapat menunjukkan semakin baik pula kinerja jangka pendek perusahaan, sehingga investor akan semakin percaya kepada perusahaan tersebut. Hal itu akan berimbas pada peningkatan harga saham dan akan berakibat pada naiknya return saham, sehingga investor dapat menerima returnyang tinggi dan sebaliknya.

Selain risiko sistematis dan likuidiitas return juga menjadi hal yang perlu diperhatikan, karena return merupakan suatu pengembalian yang diperoleh dari suatu dana atau modal yang ditanamkan pada suatu investasi. Return saham dibedakan menjadi dua jenis Hartono (2007:109), yaitu return realisasi (realized return) dan return eks-pektasi (expected return). Return realisasi merupakan return yang sudah terjadi yang dihitung berdasarkan data historis. Return realisasi ini penting dalam mengukur kinerja dan sebagai penentuan return dan resiko di masa yang akan datang, sedang-kan return ekspektasi merupakan returnyang diharapkan terjadi di masa yang akan datang dan masih bersifat tidak pasti.

Peneliti melakukan penelitian terhadap return saham, risiko sistematis dan tingkat likuiditas karena, semakin berkembangnya pasar modal di Indonesia menuju ke arah yang efisien dimana semua informasi yang relevan bisa dipakai sebagai masukan untuk menentukan return saham dan kecenderungan investor untuk menolak risiko (risk averse), sehingga aspek informasi tersebut dapat dijadikan sebagai dasar pengambilan keputusan.

\section{LANDASAN TEORI \\ Risiko Sistematis}

Fahmi dan Hadi (2013:151) dalam buku yang berjudul Teori Portofolio dan Analisis Investasi mengemukakan risiko adalah sebagai bentuk keadaan ketidakpastian tentang suatu keadaan yang akan terjadi nantinya dengan keputusan yang diambil berdasarkan suatu pertimbangan.Menurut Halim (2002:40) dalam konteks portofolio risiko dibedakan menjadi dua, yaitu:

a) Risiko Sistematis (systematic risk)

Risiko Sistematis merupakan risiko yang tidak dapat dihilangkan dengan melakukan diversivikasi, karena fluktuasi risiko ini dipengaruhi oleh faktor-faktor makro yang dapat mempengaruhi pasar secara keseluruhan. Misalnya adanya perubahan tingkat suku bunga, kurs valas, kebijakan pemerintah. 
b) Risiko tidak sistematis (unsystematic risk)

Risiko tidak sistematis merupakan risiko yang dapat dihilangkan dengan melakuakn diversifikasi, karena risiko ini hanya ada dalam satu perusahaan atau industri tertentu. Fluktuasi risiko ini berbeda-beda antara satu saham dengan saham yang lain. Karena perbedaan itulah maka masing-masing saham memiliki tingkat sensitivitas yang berbeda terhadap setiap perubahan pasar. Faktor yang mempengaruhinya antara lain, struktur modal, struktur aset, tingkat likuiditas, dan tingkat keuntungan. Beta (b) merupakan suatu ukuran tingkat risiko suatu sekuritas didalam hubungannya dengan pasar sekuritas itu sendiri. Jadi Beta digunakan untukmengukur nondiversifiable risk atau market risk (risiko pasar) Husnan (1998) dalam Alfred (2005).

Beta suatu sekuritas dapat dihitung dengan teknik estimasi yang menggunakan data historis. Beta yang dihitung berdasarkan data historis selanjutnya dapat digunakan untuk mengestimasi beta dimasa datang. Beta historis dapat dihitung dengan menggunakan data historis berupa data pasar (return sekuritas dan return pasar), data akuntansi (laba-laba perusahaan dan laba indeks pasar). Beta yang dihitung dengan data pasar disebur beta pasar, beta pasar dapat diestimasi dengan mengumpulkan nilai-nilai historis return dari sekuritas dan return dari pasar selama periode tertentu, misal selama 60 bulan untuk return bulanan atau 200 hari untuk return harian (Hartono, 2007:267).

\section{Likuiditas}

Likuiditas adalah kesanggupan perusahaan memenuhi kewajiban keuangan yang segera jatuh tempo, atau mengukur kemampuan membayar utang-utang yang jatuh tempo, (Wasis, 1991:36). Menurut Irham (2013:147) likuiditas merupakan gambaran kemampuan suatu perusahaan dalam memenuhi kewajiban jangka pendeknya secara lancar dan tepat waktu sehingga likuiditas sering disebut dengan short term equity.

Dari pengertian ini dapat disimpulkan bahwa likuiditas adalah kemampuan pembayaran yang dimiliki oleh perusahaan dalam suatu periode tertentu berupa aktiva untuk melunasi semua kewajiban jangka pendek perusahaan yang telah jatuh tempo atau segera ditagih. Perusahaan dikatakan likuid apabila perusahaan tersebut mampu memenuhi kewajiban-kewajibannya tepat pada waktunya, akan tetapi apabila perusahaan tidak mampu memenuhi kewajiban-kewajiban yang telah jatuh tempo ini tepat pada waktunya, dapat dikatakan bahwa perusahaan tersebut tidak likuid, (Aufa, 2013).

Salah satu alat ukur dari likuiditas ini adalah dengan menggunakan rasio lancar (current ratio). Current ratio merupakan rasio untuk mengukur kemampuan perusahaan dalam membayar kewajiban jangka pendek atau hutang yang segera jatuh tempo pada saat ditagih secara keseluruhan (Kasmir, 2011:134).

\section{Return Saham}

Hartono (2007:109) mengemukakan return dapat berupa tingkat pengembalian realisasi yang sudah terjadi atau tingkat pengembalian ekspektasi yang belum terjadi tetapi yang diharapkan akanterjadi di masa mendatang. Sedangkan menurut Tandelilin (2001) dalam Davesta (2014) return merupakan salah satu faktor yang memotifasi investor berinvestasi dan juga merupakan imbalan atas keberanian investor menanggung risiko atas investasi yang dilakukannya.

Fahmi dan Hadi (2013:151) mengartikan return adalah keuntungan yang diperoleh oleh perusahaan, individu dan institusi dari hasil kebijakan investasi yang dilakukannya. Dalam berinvestasi seorang investor mengharapkan expected return, expected return adalah keuntungan yang diharapkan oleh seorang investor di kemudian hari terhadap sejumlah dana yang telah ditempatkanya (Fahmi, 2013: 152). Untuk mengetahui sebuah untung rugi investasi perlu mengetahui capital gain, capital gainmerupakan selisih untung (rugi) dari harga investasi sekarang relatif dengan harga periode yang lalu. Jika harga investasi sekarang lebih tinggi dari harga investasi periode lalu ini berarti terjadi keuntungn modal (capital gain), apabila sebaliknya maka terjadi kerugian modal (capital loss), (Hartono, 2007:110). 


\section{Kerangka Berpikir}

Kerangka pemikiran dalam penelitian ini dapat digambarkan sebagai berikut :

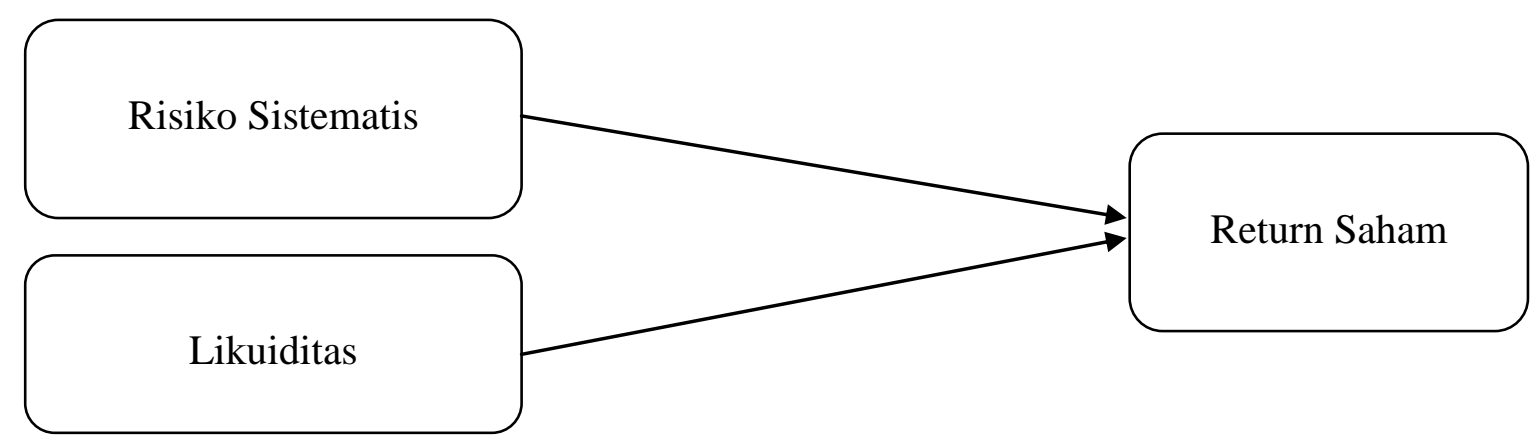

Gambar 1. Kerangka Berpikir

\section{PENGEMBANGAN HIPOTESIS}

Risiko Sistematis

Risiko sistemetis (Beta) merupakan suatu pengukur volatilitas return sekuritas atau return portofolio terhadap return pasar. Volatilitas sendiri dapat didefinisikan sebagai fluktuasi dari return - return suatu sekuritas atau portofolio dalam suatu periode waktu tertentu, fluktuasi juga merupakan suatu pengukur risiko. Bila Beta bernilai 1 menunjukkan bahwa return pasar bergerak naik, return sekuritas atau portofolio juga bergerak naik sama besarnya mengikuti return pasar.Beta bernilai 1 menunjukkan bahwa perubahan return pasar sebesar x\% (Hartono, 2007:266).

Penelitian yang dilakukan oleh Elly dan Leng (2002) yang mengambil sampel pada perusahaan yang terdaftar pada BEJ pada tahun 1999 dengan hasil penelitian menyatakan bahwa ada pengaruh yang signifikan antara risiko sistematis terhadap return. Bila beta naik maka investor mengharapkan return yang semakintinggi untuk menutupi tambahan risiko yang ditanggung/sebaliknya. Berdasarkan hal tersebut maka hipotesis yangdiajukan adalah:

H1 : Risiko Sistematis berpengaruh positif dan signifikan terhadap return saham.

\section{Likuiditas}

Dalam berinvestasi, saham yang memiliki tingkat likuiditas yang rendah maka biaya likuiditasnya akan besar, jadi investor akan mengharapkan tingkat return yang tinggi. Hipotesis ini berusaha dibuktikan oleh Elly dan Leng (2002) yang mengambil sampel pada perusahaan yang terdaftar pada BEJ pada tahun 1999 hasil penelitian menyatakan bahwa likuiditas berpengaruh secara signifikan terhadap return. Investor akan menginvestasikan dana pada sekuritas dengan risiko tinggi dan tingkat likuiditas yang rendah dengan mengharapkan tingkat return yang tinggi. Berdasarkan hal tersebut maka hipotesis yang diajukan adalah

\section{H2 : Likuiditas berpengaruh positif dan signifikan terhadap return saham.}

\section{HASIL DAN PEMBAHASAN \\ Deskripsi dan Objek Penelitian}

Perusahaan yang dijadikan sebagai sampel pada penelitian ini adalahindustri manufaktur yang listing di Bursa Efek Indonesia periode tahun 2012-2014 sesuai dengan kriteria metode purposive sampling yaitu pemilihan sampel tidak acak yang informasinya diperoleh dengan pertimbangan tertentu. Dan telah memenuhi kriteria pengambilan sample yaitu 30-100 sample (Sugiyono, 2011:128).

Adapun kriteria-kriteria yang digunakan adalah sebagai berikut :

1) Perusahaan manufaktur yang terdaftar di Bursa Efek Indonesia dan mempublikasikan laporan keuangan pada tahun 2012, 2013, 2014.

2) Perusahaan manufaktur yang terdaftar di BEI dan tidak mengalami delisting selama periode pengamatan.

3) Menerbitkan laporan keuangan auditan yang dipublikasikan selama tahun 2012, 2013, 2014 secara berturut-turut. 
4) Perusahaan yang mempublikasikan harga saham pada tanggal publikasi.

Berdasarkan kriteria tersebut terpilih sebanyak 33 perusahaan.

\section{Analisis Data}

\section{Uji Asumsi Klasik}

Sebelum pengujian regresi terlebih dahulu dilakukan pegujian asumsi klasik yang berguna untuk mengetahui apakah data yang digunakan telah memenuhi ketentuan dalam model regresi, uji ini meliputi:

\section{Uji Normalitas}

Uji ini untuk mengetahui apakah distribusi data yang di gambarkan dalam diagram tersebut normal atau tidak. Uji

Normalitas dilakukan dengan uji Kolmogorov Smirnov dan Grafik Normal Plot.

Tabel 1.Uji Kolmogorov Smirnov.

\begin{tabular}{l}
\hline \\
Unstandardized \\
Residual
\end{tabular}

Gambar 2.Grafik Normal Plot

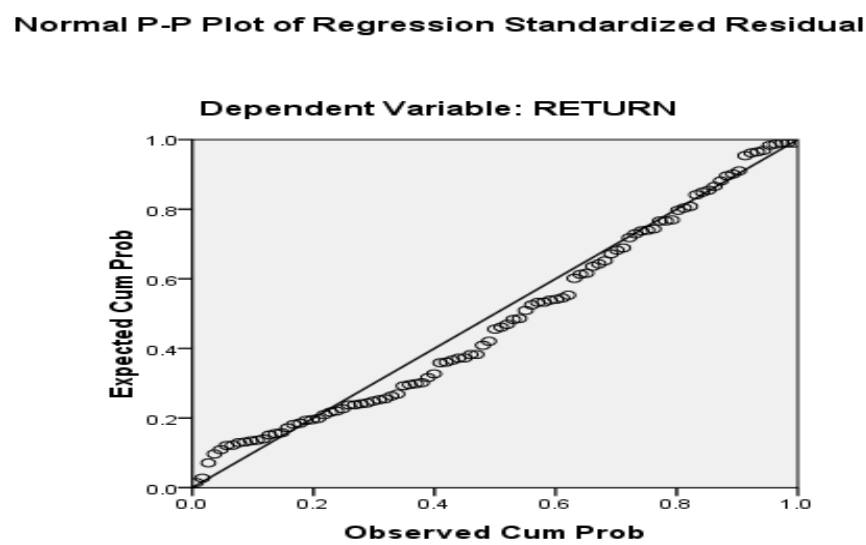

Sumber : Data sekunder yang diolah, 2015

Pada Gambar 2. grafik normal plot di atas terlihat bahwa titik-titik menyebar disekitar garis diagonal, dan penyebarannya mengikuti arah garis diagonal, sehingga dapat disimpulkan secara keseluruhan asumsi normalitas dari residual dapat diterima.Dari kedua grafik di atas dapat disimpulkan bahwa model regresi memenuhi asumsi normalitas.

\section{Uji Multikolonieritas}

Pengujianpada penelitian ini dilakukan dengan melihat nilai Tolerance Value dan Variance Inflation Factor (VIF). Hasil pengujian terlihat pada Tabel 2. sebagai berikut:
Tabel. 2.Hasil Uji Multikolonieritas

\begin{tabular}{|c|c|c|}
\hline \multirow[b]{2}{*}{ MODEL } & \multicolumn{2}{|c|}{ Collinearity Statistics } \\
\hline & Tolerance & VIF \\
\hline \multicolumn{3}{|l|}{ (Constant) } \\
\hline BETA & 991 & 1,010 \\
\hline LIKUIDITAS & ,991 & 1,010 \\
\hline
\end{tabular}

Sumber : Data sekunder yang diolah, 2015

Uji multikolonieritas bertujuan untuk menguji apakah model regresi ditemukan adanya korelasi antar variabel bebas (independent variable). Model regresi yang baik seharusnya tidak terjadi korelasi diantara variabel bebas. Multikolonieritas terjadi apabila 
(1) nilai tolerance ( Tolerance < 0.10) dan (2) variance inflation factor (VIF > 10). Berdasarkan Tabel. 2. terlihat nilai VIF untuk variabel Likuiditas dan Beta lebih kecil dari 10. Sedangkan nilai tolerance nya lebih besar dari 0,10. Hal ini menunjukkan bahwa variabel bebas dalam penelitian ini tidak saling berkorelasi atau tidak ditemukan adanya korelasi antara variabel bebas, sehingga model tidak mengandung multikolonieritas.

\section{Uji Heterokedastisitas}

Untuk menentukan heteroskedastisitas menggunakan grafik scatterplot, titik-titik yang terbentuk harus menyebar secara acak,tersebar baik diatas maupun dibawah angka 0 pada sumbu Y, bila kondisi ini terpenuhi maka tidak terjadi heteroskedastisitas dan model regresilayak digunakan. Hasil uji heteroskedastisitas dengan menggunakan grafik scatterplot di tunjukan pada Gambar 3 dibawah ini:

\section{Gambar 3.Scatterplot}

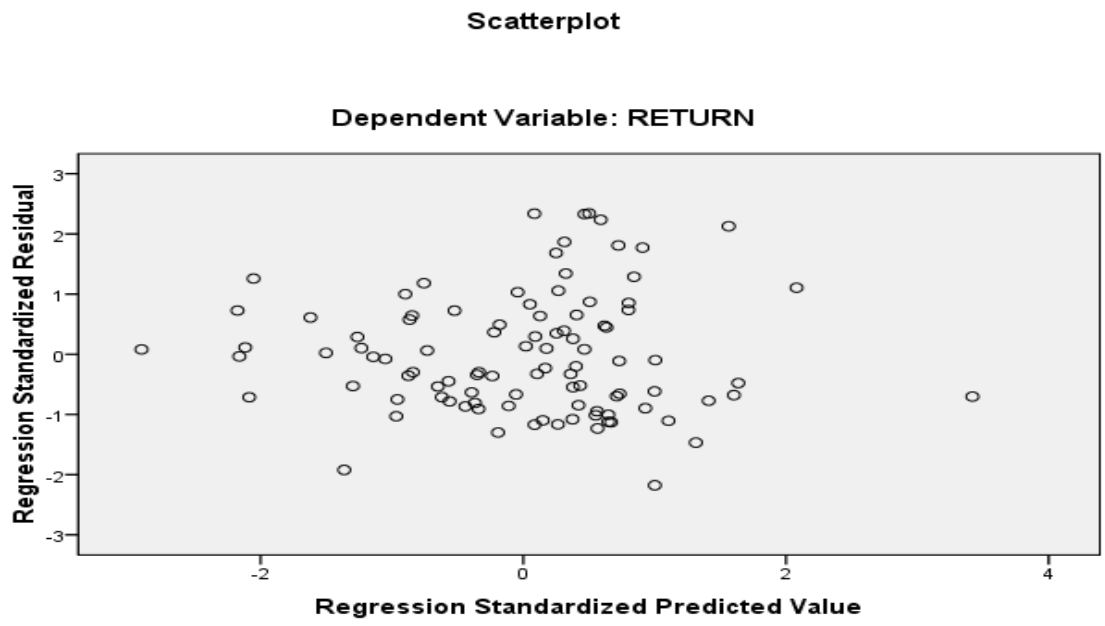

Sumber : Data sekunder yang diolah, 2015

Dari Gambar 3. scatterplot terlihat bahwa titik-titik menyebar secara acak serta tersebar baik di atas maupun di bawah angka 0 (nul) pada sumbu Y. Hal ini dapat disimpulkan bahwa tidak terjadi heteroskedastisitas pada model regresi, sehingga model regresi layak dipakai untuk memprediksi harga saham berdasarkan masukan variabel bebas (independent) Likuiditas dan Risiko Sistematis (Beta).

\section{Uji Autokorelasi}

Pendeteksian masalah autokorelasi dilakukan dengan pengujian Durbin-Watson atau uji d. Nilai d memiliki batas 0 sampai dengan 4 , dan juga memiliki batas bawah dL dan juga batas atas dU. Dari Tabel 3. diperoleh nilai hitung Durbin-Watson sebesar 2,075.

Tabel 3. Uji Autokorelasi

\begin{tabular}{cccccc}
\hline Model & $\mathrm{R}$ & $\begin{array}{c}\mathrm{R} \\
\text { Square }\end{array}$ & $\begin{array}{c}\text { Adjusted } \mathrm{R} \\
\text { Square }\end{array}$ & $\begin{array}{c}\text { Std. Error of the } \\
\text { Estimate }\end{array}$ & $\begin{array}{c}\text { Durbin- } \\
\text { Watson }\end{array}$ \\
\hline 1 &, $357^{\mathrm{a}}$ &, 127 &, 109 & 42,2883193 & 2,075 \\
\hline
\end{tabular}

Berdasarkan hasil hitung Durbin Watson sebesar 2,075;sedangkan dalamtabel DW untuk "k"=2 dan N=99 besarnya DW-tabel: $d l$ (batas luar $)=1,693 ; d u($ batas dalam $)=1,714 ; 4-d u$ $=2,286 ;$ dan $4-d l=2,307$ maka dari perhitungan disimpulkan bahwa DW-test 
terletak padadaerah uji. Hal ini dapat dilihat pada Gambar 4 sebagai berikut:

\section{Gambar 4. Hasil Uji Durbin Watson}

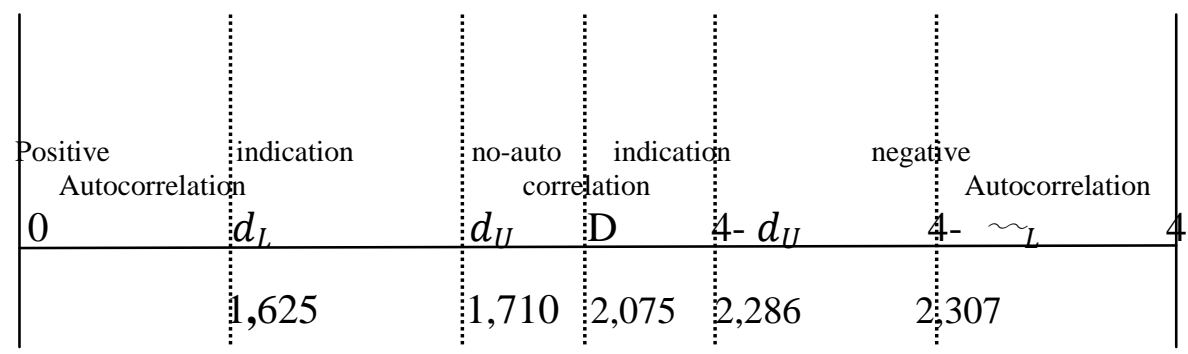

Sesuai dengan Gambar 4. tersebut menunjukkan bahwa angka DurbinWatson berada di daerah no autocorrelation.

\section{Model Analisi Regresi Berganda}

Analisis ini digunakan untuk mengetahui seberapa besar pengaruh risiko sistematis
(X1)dan likuiditas saham (X2) terhadap return saham (Y), dan tujuannya adalah untuk meramalkan atau memperkirakan nilai variabel dependen dan hubungannya dengan variabel lain. Dari hasil perhitungan dengan menggunakan program SPSS, maka bentuk persamaan regresinya adalah sebagai berikut :

Tabel 5. Hasil Coefficients

\begin{tabular}{|c|c|c|c|c|c|}
\hline \multirow[b]{2}{*}{ Model } & \multicolumn{2}{|c|}{$\begin{array}{l}\text { Unstandardized } \\
\text { Coefficients } \\
\end{array}$} & \multirow{2}{*}{$\begin{array}{l}\text { Standardized } \\
\text { Coefficients } \\
\text { Beta }\end{array}$} & \multirow[b]{2}{*}{$\mathrm{t}$} & \multirow[b]{2}{*}{ Sig. } \\
\hline & B & Std. Error & & & \\
\hline (Constant) & 27,762 & 7,760 & & 3,578 & ,001 \\
\hline BETA & $-126,823$ & 34,872 &,- 348 & $-3,637$ & ,000 \\
\hline LIKUIDITAS & 031 & ,025 & ,118 & 1,237 & 219 \\
\hline
\end{tabular}

Berdasarkan hasil uji tersebut, maka diperoleh persamaan regresi linear berganda sebagai berikut:

$$
Y=27,762-126,823(X 1)+0,031(X 2)+e
$$

Angka yang dihasilkan dari pengujian tersebut dijelaskan sebagai berikut:

\section{a) Konstantan ( $\alpha$ )}

Nilai konstanta yang diperoleh sebesar 27,762 . Hal ini berarti jika variabel independen (X1 dan X2) tidak ada, maka besarnya akumulasi return tidak normal pada saham yang terjadi adalah sebesar 27,762 .

b) Koefisien Regresi ( $\beta$ ) X1

Nilai koefisien regresi variabel risiko sistematis (X1) sebesar -126,823. Hal ini menandakan, setiap kenaikan satu satuan risiko sistematis yang diukur dengan beta akan mengakibatkan penurunan return saham sebesar $-126,823$.

c) Koefisien Regresi ( $\beta)$ X2

Nilai koefisien regresi variabel Likuiditas (X2) sebesar0,031. Hal ini menandakan, setiap kenaikan satu satuan Likuiditas yang diukur dengan current ratio (CR) akan mengakibatkan kenaikan return saham sebesar 0,031.

\section{Uji Hipotesis}

\section{Uji Koefisien Determinasi $\left(\mathbf{R}^{\mathbf{2}}\right)$}

Koefisien determinasi (R2) digunakan untuk menjelaskan pengaruhdarivariabel independen terhadap variabel dependen.Berdasarkan hasil perhitungan dengan menggunakan program SPSS, maka hasil koefisien determinasi (R2) dapat diterangkan sebagai berikut : 
Tabel 6. Hasil Koefisien Determinasi (R2)

\begin{tabular}{llllll}
\hline Model & $\mathrm{R}$ & $\mathrm{R}$ Square & $\begin{array}{l}\text { Adjusted } \\
\text { Square }\end{array}$ & $\begin{array}{c}\text { R Std. Error of the } \\
\text { Estimate }\end{array}$ & \begin{tabular}{l} 
Durbin-Watson \\
\hline 1
\end{tabular} \\
\hline $357^{\mathrm{a}}$ &, 127 &, 109 & 42,2883193 & 2,075 \\
\hline
\end{tabular}

Sumber : Data sekunder yang diolah, 2015

Berdasarkan Table 6. di atas menunjukkan bahwa nilai adjust R-Square adalah 0,109, dengan demikian pengaruh variabel independen (likuiditas dan risiko sistematis) adalah sebesar 10,9\%, sedangkan sisanya 80,9 \% dipengaruhi oleh variabel lain di luar penelitian misalnya harga saham, dan tingkat suku bunga.

\section{Uji Simultan (Uji F)}

Berdasarkan hasil output SPSS nampak bahwa pengaruh secara bersama-sama dua variabel independen tersebut (Risiko Sistematis dan Likuiditas) terhadap Return seperti ditunjukkan pada Table 7 .

\begin{tabular}{llllll}
\multicolumn{5}{c}{$\begin{array}{c}\text { Tabel 7.Uji F } \\
\text { ANOVA }^{\mathbf{b}}\end{array}$} \\
\hline Model & Sum of Squares & Df & Mean Square & F & Sig. \\
\hline 1Regression & 25062,233 & 2 & 12531,116 & 7,007 &, $001^{\text {a }}$ \\
Residual & 171676,987 & 96 & 1788,302 & & \\
Total & 196739,220 & 98 & & & \\
\hline
\end{tabular}

Dari hasil perhitungan diperoleh nilai $\mathrm{F}$ sebesar 7,007 dan nilaisignifikansi sebesar 0,001. Karena nilai signifikansi lebih kecil dari $5 \%$ modelpersamaan dalam penelitian ini yang menguji pengaruh Risiko Sistematis dan Likuiditas terhadap Return Saham. Hal ini berarti bahwa persamaan regresi yang diperoleh dapat diandalkan atau model yang digunakan sudah fixdanlayak untuk diteliti.

\section{Uji Parsial (Uji t)}

Uji t dilakukan untuk menguji pengaruh dari masing-masing variableindependen (likuiditas dan risiko sistematis ) terhadap variabel dependen (returnsaham). Apabila nilai Sig $t<$ tingkat signifikansi $(0,05)$ maka H0ditolak, sedangkan bila nilai Sig $\mathrm{t}>0,05$ maka $\mathrm{HO}$ diterima.

Tabel 8. Hasil Pengujian Parsial (Uji t)

\begin{tabular}{lll}
\hline \multicolumn{1}{c}{ Variabel } & \multicolumn{1}{c}{ Koefisien } & Signifikansi \\
\hline Konstanta & 3,578 & 0,001 \\
Risiko Sistematis (Beta) & $-3,637$ & 0,000 \\
Likuiditas & 1,237 & 0,219 \\
\hline
\end{tabular}

Berdasarkan hasl uji $\mathrm{t}$ yang tampak dalam Table 8. di atas, maka dapat diambil kesimpulan sebagai berikut:

1. Variabel Risiko Sistematis (Beta Saham)

Terdapat nilai sig risiko sistematis 0,000 , dimana nilai sig lebih kecil dari nilai probabilitas 0,05 atau nilai $0,000<0,05$, yang berarti $\mathrm{H} 0$ ditetima dan Ha ditolak. Dilihat dari nilai thitung $-3,637$ dengan $t$ tabel sebesar1,66 jadi thitung < ttabel, maka variabel X1 mempunyai hubungan yang tidak searah dengan variabel Y Berdasarkan hasil analisis tersebut, diketahui bahwa variabel X1 (risiko sistematis) berpengaruh signifikan negatif terhadap return saham.

\section{Variabel Likuiditas}

Berdasarkan Table 8. terdapat nilai sig likuidutas 0,219. Dimana nilai sig lebih besardarinilai probabilitas 0,05 atau nilai $0,219>$ 
0,05, makaberarti H0 diterima dan Ha ditolak. Dan dilihat dari nilai $\mathrm{t}$ hitung yakni 1,237 denganttabel sebesar 1,666, jadi thitung < ttabel yang variabel $\mathrm{X} 2$ tidak mempunyai hubungan yang searah dengan variabel $\mathrm{Y}$ Berdasarkan hasil analisis tersebut, diketahui bahwa variabel X2 (likuiditas saham) berpengaruh positif dan tidak signifikan terhadap variabel $\mathrm{Y}$ (return saham).

\section{Pengaruh risiko sistematis terhadap return saham perusahaan manufaktur.}

Berdasarkan hasil pengujian secara parsial (uji t) diketahui bahwa risiko sistematis berpengaruh negatif terhadap return saham industri manufaktur yang terdaftar di Bursa Efek Jakarta dengan thitung $-3,637<$ ttabel $=$ 1,666 dan nilai sig. 0,000 . Hasil penelitian ini mendukung penelitian Rachmatika (2006) yang menyatakan bahwa secara partial variabel Beta Saham berpengaruh signifikan negatif terhadap variabel Return Saham. Alasan beta mempunyai pengaruh yang negatif dikarenakan kebijakan manajemen cenderung melakukan restrukturisasi hutang, dimana manajemen lebih hati-hati dalam menanamkan investasinya kedalam proyek-proyek investasi yang menguntungkan karena dengan meminimalkan resiko akan meraih keuntungan yang optimal.

Hasil penelitian ini tidak sejalan dengan hasil penelitian yang dilakukan oleh Alfred (2005) dan Yunina (2013) yang menyatakanRisiko sistematik berpengaruh signifikan positif terhadap return saham. Dimungkinkan seorang investor dalam berinvestasi mengharapkan keuntungan yang akan didapat pada masa datang dengan mempertimbang kanrisiko yang berkaitan dengan saham yaitu risiko sistematis yaitu risiko yangberasal dari faktor - faktor yang mempengaruhi perusahaan secara langsung, seperti ketidakpastian kondisi ekonomi (tingkat inflasi, gejolak nilai tukar mata uang, dan tingkat suku bunga yang tidak menentu). Hal ini dapat mengakibatkan kinerja saham suatu perusahaan sangat dipengaruhi oleh kondisi yang terjadi dalam perekonomian negara dan perubahan pasar. Dapat diartikan juga, tingkat pengembalian saham sangat dipengaruhi oleh perubahan faktor - faktor diluarkendali suatu badan usaha.

Tidak berpengaruhnya risiko sistematis (beta) saham terhadap return saham dapat juga disebabkan oleh faktor psikologis investor yang ingin selalu memperoleh return semaksimal mungkin. Teori tentang high risk high return juga tidak selamanya sesuai dengan investor karena terkadang tidak semua investor menyukai tantangan. Investor cenderung bersifat risk averse (menghindari risiko) ketika risiko suatu perusahaan terlalu tinggi. Dengan sifat yang ingin menghindari risiko itulah, dapat berakibat pada kurangnya minat investor terhadap saham di suatu perusahaan sehingga harga saham turun dan berdampak pada rendahnya return yang akan diterima.

\section{Pengaruh likuiditas terhadap return saham perusahaan manufaktur.}

Berdasarkan hasil uji secara parsial (uji t) likuiditas saham berpengaruh positif terhadap return saham industri manufaktur dimana thitung $=1,237<$ tabel $=1,666$ dan nilai sig 0,219 dimana nilai sig lebih besardarinilai probabilitas 0,05 yang menunjukkan pengaruh tidak signifikan terhadap return saham industri manufaktur yang terdaftar di Bursa Efek Indonesia.

Hasil penelitian ini tidak sejalan dengan hasil penelitian yang dilakukan oleh Elly dan Leng(2002) dan Alfred (2005)yang menyatakan bahwa secara individu risiko sistematis dan likuiditas mempunyai pengaruh yang positif dan signifikan terhadap return. Namun secara partial hasil uji $\mathrm{t}$ terhadap likuiditas saham pada penelitian ini sejalan dengan penelitian Davesta (2012) dan Aufa (2013) yang mengatakan bahwa secara individu faktor likuiditas mempunyai pengaruh yang tidak signifikan terhadap return saham.

Likuiditas yang digunakan untuk mengukur kemampuan perusahaan untuk memenuhi kewajiban jangka pendeknya dengan aktiva lancar yang dimilikinya. Current Ratio (CR) yang dimiliki menunjukkan besarnya kemampuan perusahaan dalam memenuhi kebutuhan operasionalnya terutama modal kerja yang sangat penting untuk menjaga performance kinerja perusahaan. Likuiditas tidak 
berpengaruh terhadap return saham hal ini disebabkan karena perusahaan dapat memenuhi kebutuhan operasionalnya dalam memenuhi kewajiban jangka pendek yeng berasal bukan dari penjualan saham maupun obligasi melainkan dari aktiva lancar yang dimiliki perusahaan tersebut

\section{Pengaruh risiko sistematis dan likuiditas terhadap return saham}

Berdasarkan uji secara simultan menunjukkan hasil risiko sistematis dan likuiditas secara bersama-sama mempunyai pengaruh terhadap return saham yang ditunjukkan dengan uji simultan (f) nilai signifikansi 0,001. Hasil ini mendukung penelitian Elly dan Leng(2002) yang menunjukkan secara bersama-sama faktor risiko sistematis dan likuiditas yang diukur dengan besarnya bid-ask spread mempunyai pengaruh yang signifikan terhadap tingkatpengembalian saham dari badan-badan usaha yang go public di Indonesia. Dan untuk lebih spesifik ditunjukan melalui uji R squere dengan hasil 0,109, dengan demikian pengaruh variabel independen (likuiditas dan risiko sistematis) adalah sebesar $10,9 \%$, sedangkan sisanya $80,9 \%$ dipengaruhi oleh variabel lain di luar penelitianmisalnya harga saham, dan tingkat suku bunga. Walaupun dalam uji secara parsial menunjukan bahwa masing-masing variabel memiliki hasil yang berbeda yaitu risiko sistematis berpengaruh signifikan negatif terhadap return saham dan likuiditas tidak signifikan terhadap return saham. Hasil uji simultan juga memperlihatkan masih banyak faktor lain di luar risiko sistematis dan likuiditas yang berpengaruh terhadap return saham yang patut untuk diteliti.

\section{PENUTUP}

\section{Kesimpulan dan Saran}

Penelitian ini merupakan penelitian empiris yang menganalisis pengaruh risiko sistematis (beta) dan likuiditas terhadap return saham. Berdasarkan hasil penelitian dan pembahasan didapatkan kesimpulan sebagai berikut:
1. Pengujian statistik secara parsial menunjukkan bahwa risiko sistematis

berpengaruh negatif dan signifikan terhadap return saham, dengan hasil thitung -3,637dan dan nilai sig. 0,000 sehingga hipotesis dalam penelitian ini diterima. Hasil penelitian ini mendukung penelitian Rachmatika (2006) yang menyatakan bahwa secara parsial variabel Risiko Sistematis (Beta) berpengaruh signifikan negatif terhadap variabel Return Saham.

2. Pengujian statistik secara parsial menunjukkan bahwa variabel likuiditas berpengaruh secara positif dan tidak signifikan terhadap return saham, dengan hasil thitung $=1,237$ dan nilai sign 0,219 , sehingga hipotesis dalam penelitian ini ditolak. Davesta (2012) dan Aufa (2013) yang mengatakan bahwa secara individu faktor likuiditas mempunyai pengaruh yang tidak signifikan terhadap return saham.

3. Pengujian statistik secara simultan menunjukkan bahwa variabel risikosistematis (beta) dan likuiditas secara bersama-sama berpengaruh signifikanterhadap return saham, dengan hasil signifikansi 0,001. Hasil ini mendukung penelitian Elly dan Leng(2002) yang menunjukkan secara bersama-sama faktor risiko sistematis dan likuiditas yang diukur dengan besarnya bidask spread mempunyai pengaruh yang signifikan terhadap tingkatpengembalian saham dari badan-badan usaha yang go public di Indonesia.

Dari kesimpulan yang telah diperoleh dari hasil penelitian ini, maka dapat diberikan beberapa saran sebagai berikut:

1. Masih banyak variabel lain diluar penelitian ini yang berpotensi mempengaruhi return saham untuk dapat diteliti lebih lanjut seperti ROE, inflasi, dan tingkat suku bunga.

2. Penelitian selanjutnya dapat menambahkan periode tahun pengamatan dan periode tahun terbaru sehingga dapat menggambarkan kondisi perusahaan sebenarnya.

3. Menambah jumlah sample perusahaan yang diteliti karena dalam penelitian ini hanya 33 sample perusahaan.

4. Menggunakan pemilihan metode sample dengan metode lain agar hasil lebih akurat. 


\section{DAFTAR PUSTAKA}

Alfred, Joan. 2005. Pengaruh RisikoSistematis (Beta) dan LikuiditasTerhadap Return saham Perusahaan LQ-45 Periode Tahun 2001. Skripsi. Semarang: Universitas Katolik Soegijapranata.

Aufa, Rahmatul. 2013. Pengaruh Struktur Modal, Risiko Sistematis, dan Tingkat Likuiditas Terhadap Return saham Pada Perusahaan Finance Yang Listing Di Bursa Efek Indonesia. Skripsi. Padang: Universitas Negri Padang.

Baridwan, Zaki. 2010. Intermediate accounting. Edisi kedelapan. BPFE Fakultas Ekonomi dan bisnis Universitas Gajah Mada. Yogyakarta.

Davesta, Revail. 2012. Pengaruh Resiko Sistematis dan Likuiditas Saham Terhadap Return Saham pada Industri Pertambangan yang Terdaftar di Bursa Efek Indonesia PeriodeTahun 20102012. Skripsi. Padang: Universitas Andalas.

Elly dan Leng. 2002. Pengaruh Risiko Sistematis dan Likuiditas Terhadap Tingkat Pengembalian Saham BadanBadan Usaha yang Go Publik Di Bursa Efek Jakarta Pada Tahun 1999. Jurnal Manajemendan Kewirausahaan. Vol. 19: hal 15 - 25. Maret 2002. Universitas Kristen Petra.

E.A. Koetin. 2000. Suatu Pedoman Invetasi Indonesia. Sinar Harapan: Jakarta.

Fahmi,Irham. 2013.Rahasia Saham Dan Obligasi, Strategi Meraih Keuntungan Tak Terbatas Dalam Bermain Saham dan Obligasi. Alfabeta. Bandung.

Fahmi, Irham dan Hadi, Yovi Lavianti. 2011. Teori Portofolio dan Analisis Investasi. Alfabeta. Bandung.

Ghozali, Imam. 2011. Aplikasi Analisis Multivariate dengan program IBM SPSS 19. Edisi V. Universitas Diponegoro. Semarang.
Hadi, Nor. 2013. Pasar Modal. Graha Ilmu: Yogyakarta

Husnan, Suad. 2005. Dasar - dasar Teori Portofolio dan Analisis Sekuritas, Edisi Keempat. Yogyakarta.

Husein, Umar. 2002. Researc Method In Financial And Banking. Jakarta: PT. Gramedia Pustaka Utama.

Hartono, Jogiyanto. 2007. Teori Portofolio dan Analisis Investasi. Edisi Ketiga. Yogyakarta : BPFE.

Indriantoro, Nurdan Bambang Supomo. 1998. Metodologi Penelitian Bisnis Untuk Akuntansi dan Manajemen. Edisi Pertama. Cetakan Pertama. BPFE: Yogyakarta.

Kasmir. 2011. Analisis laporan keuangan. Jakarta: Rajawali Persada.

Mawadwasrista, Putu Anom, 2001, Analisis Ekonometri: Pengaruh Return Volume Transaksi dan Risiko Unik Saham Terhadap Beta Perusahaan Industri Rokok. Jurnal Riset Akuntansi, Manajemen dan Akuntansi, Vol. 1 no 2, hal $177-190$.

Rachmatika, Dian. 2006. Analisis Pengaruh Beta Saham, Growth Opportunities, Return On Asset dan Debt To Equitty Ratio Terhadap Return Saham. Tesis. Universitas Diponegoro.

Sugiri, Slamet dan Riyono Bogat Agus. (2008). Akuntansi Pengantar. UPP STIM YKPN.

Sugiyono. 2011. Metode Penelitian Kuantitatif, Kualitatif, dan $R \& D$. Alfabeta. Bandung.

Sunariyah. 2006. Pengantar Pengetahuan Pasar Modal. Yogyakarta: UPP AMP YKPN.

Sumani, Suhari, Christine. 2013. Analisis Pengaruh Risiko Sistematis Dan Likuiditas Terhadap Return Saham Dalam Perusahaan Non Keuangan LQ45 Periode Tahun 2007-2009. Jurnal Fakultas Ekonomi Unpar. Volume 17. Nomor 1. 


\section{JURNAL AKUNTANSI VOL.3 NO.2 DESEMBER 2015}

Wasis. 1991. Manajemen Keuangan Perusahaan. Semarang: Satya Wacana.

Yunina, Fitri. Dkk. Pengaruh Risiko Sistematis , Leverage, dan Laba Terhadap Return Saham Pada Perusahaan Aneka Industri di Indonesia.Jurnal Akuntansi. Universitas Syah Kuala.Vol 2. No 2

www.idx.co.id

www.yahoofinance.com

www.sahamok.com 